Volume 2 Nomor 2, Desember 2019

E-ISSN: 2655-7347

\title{
SANKSI YANG DITERIMA OLEH PEJABAT PEMBUAT AKTE TANAH DALAM PEMBUATAN AKTA AUTENTIK YANG CACAT HUKUM (STUDI PUTUSAN: PN JAKSEL NO. 124/PDT.G/2017/PN.JKT.SEL)
}

\author{
Andi Pratono \\ (Mahasiswa Program S1 Fakultas Hukum Universitas Tarumanagara) \\ (E-mail: andytsai@yahoo.co.id
}

\begin{abstract}
Tjempaka
(Corresponding Author)

(Dosen Fakultas Hukum Universitas Tarumanagara. Meraih Sarjana Hukum pada Fakultas Hukum Universitas Tulang Bawang Lampung, Magister Hukum pada Fakultas Hukum Universitas Lampung, Magister Kenotariatan pada Fakultas Hukum Universitas Diponegoro, Doktor (Dr.) pada Fakultas Hukum Universitas Trisakti)

(E-mail: not.tjempaka@gmail.com
\end{abstract}

\begin{abstract}
Indonesia is the law of state or law state, as a law state country, Indonesia must have 3(three) important element such as legal certainty, justice, and expediency. Those main elements represent all the law state. In community, people everyday acts always relate to legal act, such as contract, buying or selling object that promised. To ensure those legal act have the ability perfect proof power, those legal act poured in the form of deed. In buying and selling land, a deed of sale and purchase must be made in front authorized official like land deed officer. However land deed officer as public official do make mistake on duty, with the result that party at a disadvantage. Party that loss because of mistake land deed officer, do ask for responsibility by suing the land deed officer to compensate the losses. Land deed officer in carrying out their duties must apply the precautionary principle so as to minimize any mistakes in making the deed. Author is using normative legal research methods, supported by a data which is theory and interviews some expert in land deed officer and Code of Ethics. The legal consequences to the land deed officer due the legal acts are against the law, which is a sanction will be given. The sanction will divided in three types such as sanction according to the Civil Law, Criminal Law and Code of Ethics or Government Regulation about land deed officer.
\end{abstract}

Keywords: legal act, deed, land, land deed officer, responsibility.

\section{PENDAHULUAN}

\section{A. Latar Belakang}

Konstitusi telah menegaskan bahwa Negara Kesatuan Republik Indonesia sebagai negara hukum, yang artinya dalam segala aktivitasnya hukum dikedepankan sebagai landasan dalam menyelesaikan berbagai masalah yang 
timbul di masyarakat melalui institusi dan perangkat peraturan yang ada. Keberadaan hukum juga dimaksudkan memberikan jaminan perlindungan serta untuk mewujudkan keadilan bagi seluruh warganya yang hidup dalam kebhinekaan.

Sejalan dengan pemikiran para filsuf dalam teori utilitsanya yang mengemukakan bahwa hukum memiliki tujuan semata-mata untuk kemanfaatan bagi orang banyak. Berbeda dengan pendapat Gustav Radburch, selain kemanfaatan tujuan hukum meliputi keadilan dan kepastian. ${ }^{1}$ Dengan demikian, Menurut Jeremy Bentham maupun Radbruch memiliki kesamaan pandangan hukum harus memberikan nilai manfaat yang sebesar-besarnya bagi masyarakat yang kemudian Radbruch menambahkan hukum tidak semata-mata hanya memberikan manfaat, tetapi juga kepastian hukum dan keadilan.

Kepastian hukum merupakan tuntunan utama terhadap hukum ialah, supaya hukum menjadi positif, dalam artian berlaku dengan pasti. Hukum yang telah menjadi kesepakatan bersama harus dipatuhi, dengan demikian hukum sungguh-sungguh positif. Sedangkan kemanfaatan adalah bahwa hukum harus ditujukan untuk sesuatu yang berfaedah atau memiliki manfaat. Tujuan hukum berikutnya yaitu keadilan, menurut Radbruch bahwa keadilan sudah cukup apabila dalam penanganan kasus-kasus harus relevan dan diperlakukan secara sama. $^{2}$

Pada masyarakat, suatu perbuatan hukum harus dilakukan dengan berdasarkan hukum, seperti dalam kepemilikan suatu tanah, maka pemilik tanah itu harus membuktikan bahwa tanah tersebut adalah milik dirinya atau pemilik yang sah dengan adanya pembuktian sertipikat sebagai alas hak yang dimilikinya. Sertipikat tanah merupakan salah satu bentuk akta autentik yang dikeluarkan oleh pejabat yang diberi kewenangan untuk itu melalui ketentuan

\footnotetext{
${ }^{1}$ Lukman Santoso Az dan Yahyanto, Pengantar Ilmu Hukum (Malang: Setara Press,2016), 79.

${ }^{2}$ O. Notohamidjojo, Soal-Soal Pokok Filsafat Hukum (Salatiga: Griya Press, 2011), 33.
} 
peraturan perundang-undangan dengan tetap merujuk pada tempat dimana akta itu dibuat. Dengan demikian kepemilikan sertifikat hak milik tanah tersebut merupakan terjaminnnya suatu kepastian hukum.

Salah satu cara untuk memiliki tanah adalah melalui proses jual beli. Jual beli dapat diartikan sebagai transaksi yang telah lama dikenal dalam masyarakat, baik dalam masyarakat tradisional maupun modern. Pada umumnya transaksi jual beli secara tradisional lebih nyata transaksinya antara penjual dan pembeli saling berhadapan dan sistem pembayarannya bersifat lebih konvensional. Berbeda dengan transaksi jual beli pada masyarakat modern, tentunya tetap mengacu pada syarat-syarat yang diatur dalam peraturan perundang-undangan yang berlaku. Transaksi yang dilakukan oleh masyarakat modern, dapat dilakukan oleh para pihak, yang dibuat dalam bentuk akta di bawah tangan dan akta autentik. ${ }^{3}$ Sebelum dibuatnya akta autentik itu, para pihak dapat melakukan perjanjian pengikatan jual beli (selanjutnya disebut PPJB) sebelum dibuatnya akta jual beli dihadapan pejabat umum yang berwenang yang telah di sumpah oleh pemerintah dalam kapasitasnya untuk membuat akta autentik.

PPJB merupakan suatu bentuk perjanjian yang disepakati para pihak atas objek jual beli berupa tanah atau bangunan sebagai pengikatan pendahuluan sebelum para pihak menyepakati dibuatnya akta jual beli di hadapan notaris. Pada umumnya, praktek pembuatan PPJB sebelum dibuat terlebih dahulu ditentukan syarat-syarat tertentu atau keadaan-keadaan yang harus dilaksanakan terlebih dahulu oleh para pihak sebelum menetapkan akta jual beli di dibuat hadapan Pejabat Pembuat Akta Tanah (selanjutnya disebut PPAT). ${ }^{4}$

\footnotetext{
${ }^{3}$ H. Salim HS, Teknik Pembuatan Akta Pejabat Pembuat Akta Tanah (PPAT) (Jakarta: Rajawali Pers, 2016), 113.

$4 \quad$ Albert Aries, “Perjanjian Pengikatan Jual Beli sebagai Alat Bukti”, https://m.hukumonline.com/klinik/detail/ulasan/lt53d8fec20b060/perjanjian-pengikatan-jual-belisebagai-alat-bukti, diakses tanggal 26 September 2019.
} 
Volume 2 Nomor 2, Desember 2019

E-ISSN: 2655-7347

Dalam bahasa Inggris, akta jual beli dikenal dengan sebutan “deed of sale and purchase", sedangkan di Belanda dikenal dengan sebutan istilah "akta van verkoop en aankoop” yang berarti akta atau bukti tertulis yang berisi klausula yang berkaitan dengan jual beli. ${ }^{5}$

Bahwa ada sebuah adagium, yang menyatakan bahwa "hukum selalu tertinggal dari perkembangan masyarakat”, dengan demikian perubahan masyarakat yang begitu cepat, sehingga masyarakat sudah sadar adanya hukum untuk menjamin hak atau kepentingannya itu. Sehingga masyarakat yang ingin melakukan hubungan perdata seperti jual-beli dapat dilakukan dengan perjanjian di bawah tangan atau dihadapan notaris atau PPAT, sehingga perjanjian itu sah menurut hukum.

PPAT sebagai pejabat juga dapat dikenakan sanksi, apabila seorang PPAT terbukti melakukan tindakan melawan hukum terhadap peraturan perundangundangan maupun melanggar aturan Kode Etik PPAT yang berlaku, maka dapat dikenakan sanksi di antaranya yaitu: 1) sanksi berupa teguran; 2) peringatan; 3) Schorsing (pemecatan sementara) dari keanggotaan perkumpulan IPPAT; 4) Onzetting (pemecatan) dari keanggotaan perkumpulan IPPAT; dan 5) pemberhentian dengan tidak hormat dari keanggotaan perkumpulan IPPAT.

Adapun yang dimaksud tindakan melawan hukum di sini yaitu lebih kepada tindakan melawan hukum secara keperdataan. ${ }^{6}$ Ada juga yang prinsip-prinsip hukum yang memiliki tujuan untuk mengendalikan atau mengatur perilaku bahaya, untuk memberikan tanggungjawab atas suatu kerugian yang timbul dari hubungan interaksi sosial, dan untuk menyediakan ganti rugi terhadap korban dengan suatu gugatan yang tepat. ${ }^{7}$

\footnotetext{
H. Salim HS, Op.Cit.,113.

Munir Fuady, Perbuatan Melawan Hukum Pendekatan Kontemporer (Bandung: PT Citra Aditya Bakti, 2013), 1.

Ibid., 3.
} 
PPAT dalam melaksanakan tugas harus berdasarkan undang-undang serta nilai-nilai luhur sebagaimana dimaksud dalam Kode Etik PPAT. Dalam menjalankan tugasnya tersebut harus wajib bekerja dengan penuh rasa tanggungjawab, bersikap mandiri dengan mengedepankan sikap jujur serta tidak memihak dalam memberikan pelayanan yang baik kepada masyarakat yang memerlukan jasanya dengan penuh kecermatan dan kehati-hatian. Dengan menjalankan tugas sesuai dengan ketentuan dan kode etik, setidaknya akan terhindar dari gugatan oleh pihak lain yang merasa dirugikan karena output kinerja yang dihasilkan telah sesuai dengan aturan hukum yang berlaku.

Adakalanya pula PPAT terseret kasus hukum karena dalam menjalankan tugas dan kewenangannya bermasalah dikemudian hari sehingga dijadikan sebagai tergugat ataupun turut tergugat. Sebagaimana kasus yang akan diangkat dalam penulisan ini, PPAT digugat ke pengadilan karena dinilai telah melakukan perbuatan melawan hukum, dimana awal mulanya itu suatu perjanjian jual beli tanah antara Ir. Sugandi (Penggugat/Penjual) dan Tamziz Taryadi (Pembeli) dengan melakukan perjanjian pengikatan jual beli sebelum dilaksanakan akta jual beli. PPJB tersebut dilaksanakan dihadapan seorang Notaris/PPAT I (Tergugat II) dengan diserahkan sertifikat hak milik kepadanya melalui asistennya (Tegugat III) tersebut untuk keperluan pengecekan tanah di Kantor Badan Pertanahan Nasional (Turut Tergugat I). Setelah dibuatkan PPJB tersebut, sertifikat hak milik itu dialihkan atau dipindah tangankan kepada Notaris/PPAT II (Tergugat IV) lain tanpa pengetahuan pemilik tanah dengan alasan tidak jelas. Kemudian sertifikat itu dikembalikan oleh Notaris/PPAT II kepada asisten Notaris/PPAT I dengan menyatakan bahwa perbuatan hukum tersebut bukan wilayah kerjanya. Kemudian asisten Notaris/PPAT I memerintahkan Notaris/PPAT II yang bukan wilayah kerjanya untuk dialihkan lagi sertifikat hak milik tersebut kepada seorang Notaris/PPAT III (Tergugat V), kemudian sertifikat yang berada di kekuasaannya tersebut dibuatkan akta jual 
Volume 2 Nomor 2, Desember 2019

E-ISSN: 2655-7347

beli palsu dimana antara penjual dengan Andre Wijaya (Tergugat I) pembeli serta PPAT yang bersangkutan tidak pernah bertemu dan, karena adanya akta jual beli yang akhirnya diketahui bukan itu adalah jual beli tersebut Kantor Pertanahan Nasional (Turut Tergugat I) menerbitkan sertifikat hak milik yang baru, kemudian tanah tersebut diagunkan sebagai salah satu bank swasta yaitu Bank Standard Chartered (Turut Tergugat II). Dari serangkaian perbuatan hukum yang dilakukan para notaris dan PPAT serta pihak-pihak yang terkait, telah menimbulkan kerugian kepada pemilik tanah.

Dengan melihat kasus di atas, maka diangkatlah jurnal dengan judul “SANKSI YANG DI TERIMA OLEH PEJABAT PEMBUAT AKTA TANAH DALAM PEMBUATAN AKTA AUTENTIK YANG CACAT HUKUM (STUDI PUTUSAN: PN JAKSEL NO. 124/PDT.G/2017/PN.JKT.SEL)".

\section{A. Perumusan Masalah}

Berdasarkan uraian latar belakang di atas, maka permasahan yang dapat penulis kemukakan dalam penelitian ini adalah: Bagaimana sanksi yang di terima oleh pejabat pembuat akta tanah dalam pembuatan akta autentik yang cacat hukum?

\section{B. Metode Penelitian}

Penelitian hukum merupakan proses mencari kesesuaian aturan hukum, prinsip-prinsip hukum, maupun doktrin-doktrin hukum guna menjawab permasalahan isu hukum yang dihadapi. ${ }^{8}$ Metode penelitian dalam penulisan ini lebih menekankan pada penelitian hukum normatif dengan tujuan agar dapat dengan mudah memecahkan permasalahan isu hukum dalam penelitian ini. Pendekatan yang digunakan yaitu pendekatan undang-undang dan pendekatan kasus guna memecahkan isu hukum yang dihadapi. Jenis data yang digunakan 35. 
Volume 2 Nomor 2, Desember 2019

E-ISSN: 2655-7347

yaitu Bahan Hukum Primer yang meliputi Peraturan Perundang-Undangan terkait Pejabat Pembuat Akta Tanah, Kode Etik PPAT, Putusan Pengadilan No. 124/Pdt.G/2017/PN.Jkt.Sel. Bahan Hukum Sekunder yang meliputi literaturliteratur baik yang berbentuk tulisan yang dibukukan maupun e-book yang bersifat virtual yang isinya berkesesuaian dengan penulisan ini. ${ }^{9}$ Penelitian ini pula menggunakan bahan non-hukum yang berupa bahan-bahan hukum yaitu berupa Kamus Hukum maupun Kamus Bahas Indonesia, ensiklopedia, dan wawancara dengan narasumber (ahli hukum) sebagai pendukung data penelitian. Adapun teknik pengumpulan data dengan cara studi pustaka atau study research, dan analisis data tersebut menggunakan kualitatif, kemudian menghubungkan teori yang berhubungan dengan masalah dan akhirnya menarik kesimpulan untuk menentukan hasil pada penulisan penelitian ini.

\section{PEMBAHASAN}

\section{A. Kasus Posisi}

Bahwa Ir. Sugandi (selanjutnya disebut penggugat) adalah pemilik yang sah atas tanah dan bangunan di Jalan Niaga Hijau I No. 10 RT. 002/RW. 017, Kelurahan Pondok Pinang, Kecamatan Kebayoran Lama, Kota Administrasi Jakarta Selatan, dengan Sertifikat Hak Milik No. 3747/Pondok Pinang, Luas 310m² Gambar Situasi No. 1242/1994 tanggal 24 Februari 1994 atas nama Ir. Sugandi.

Bahwa kemudian Penggugat kemudian bermaksud untuk menjual tanahnya tersebut kepada Sdr. Tamziz Taryadi dengan cara pembayaran mencicil/tidak sekaligus, dimana Sdr. Tamziz Taryadi akan membayar uang muka terlebih dahulu kepada Penggugat.

Bahwa kemudian Sdr. Radian Sugandi (anak penggugat) dan Sdr. Tamziz Taryadi menyusun sendiri draft pengikatan jual beli dan draft tersebut kemudian

Ibid., 195. 
E-ISSN: 2655-7347

akan diserahkan kepada Notaris Agung Setiawan Badarudin (selanjutnya disebut sebagai Tergugat II) yang wilayah kerjanya di Jakarta Selatan, untuk dituangkan dalam bentuk akta autentik.

Bahwa Sdr. Radian Sugandi (anak penggugat) bersama Sdr. Tamziz Taryadi datang ke kantor Tergugat II dengan maksud untuk mengadakan transaksi jual beli tanah dan bangunan dengan cara pembayaran memakai termin (angsuran), serta dibuatkan Perjanjian Pengikatan Jual Beli/PPJB, bahwa pada saat itu Sdr. Radian Sugandi (anak penggugat) dan Sdr. Tamziz Taryadi telah membuat draft yang tentunya isi dan makna PPJB tersebut merupakan keinginan dari para pihak itu sendiri. Kemudian isi dan dan makna dalam draft PPJB tersebut yang dibuat para pihak nantinya akan dituangkan ke dalam Akta Perjanjian Pengikatan Diri untuk Melaksana Penjualan dan Pembelian (Akta PPJB).

Bahwa selanjutnya Sdr. Radian Sugandi (anak penggugat) menyerahkan asli Sertifikat Hak Milik Atas Tanah kepada Rochmani, Asisten Notaris Agung Setiawan Badarudin (selanjutnya disebut sebagai Tergugat III) untuk pengecekan di Kantor Pertanahan di Jakarta Selatan, yang mana hasil pengecekan akan diperlihatkan kepada Sdr. Tamziz Taryadi selaku calon pembeli. Kemudian dalam hal ini, Tergugat II hanya melihat asli Sertifikat Hak Milik Atas Tanah tersebut pada saat mengecek dan meneliti draft akta pasca koreksi dari para pihak, dan saat itu Sertifikat Hak Milik Atas Tanah tersebut dibawa kembali kepada Tergugat III. Selanjutnya pada tanggal 4 Mei 2016 telah terjadi Perjanjian Pengikatan Diri Untuk Melaksanakan Penjualan dan Pembeli antara Penggugat dan Sdr. Tamziz Taryadi.

Bahwa kemudian pada tanggal 29 April 2016 diserahkan atau dialihkan Sertifikat Hak Milik Atas Tanah tersebut kepada Notaris/PPAT Hasan Halim (selanjutnya disebut sebagai Tergugat IV) tanpa sepengetahuan Penggugat sebagai pemilik tanah melalui Tergugat III dan Sdr. Andrian Anton (pihak yang 
Volume 2 Nomor 2, Desember 2019

E-ISSN: 2655-7347

tidak ketahui). Kemudian Tergugat III berdalih bahwa penyerahan/pengalihan Sertifikat Hak Milik Atas Tanah sudah atas pengetahuan Sdr. Radian Sugandi (anak penggugat) dan sudah mendapatkan kuasa secara tertulis dari Penggugat. Bahwa karena adanya pengalihan oleh Tergugat III dan Sdr. Andrian Anton kepada Tergugat IV.

Bahwa setelah Tergugat IV mempelajari berkas-berkas yang diberikannya. kemudian Tergugat IV menyatakan bahwa ia tidak dapat melakukan perbuatan hukum apapun, karena bahwa objek tanah tersebut itu bukan wilayah kerjanya sebagai Notaris/PPAT. Karena Tergugat IV merupakan Notaris/PPAT di Jakarta Utara, maka pada tanggal 31 Mei 2016 Sertifikat Hak Milik Atas Tanah tersebut kemudian dikembalikan kepada Sdr. Andrian Anton dengan konfirmasi Tergugat III dengan serta membawa surat tanda terima berkas tersebut.

Bahwa pada tanggal 3 November 2016 tanpa alasan yang jelas Sertifikat Hak Milik Atas Tanah tersebut diserahkan kepada Notaris/PPAT Noor Kholis Adam (selanjutnya disebut sebagai Tergugat V), kemudian karena adanya pengalihan tersebut dilangsung akta jual beli No. 202/2016, pada tanggal 23 Mei 2016 , antara Penggugat sebagai Penjual dengan Andrie Wijaya (selanjutnya disebut sebagai Tergugat I) dan Akta Surat Kuasa Membebankan Hak Tanggungan No. 203/2016, tanggal 23 Mei 2016 antara Bank Standard Chartered, keduanya-duanya dibuat dihadapan Tergugat V selaku Pejabat Pembuat Akta Tanah, atas tanah terletak di Provinsi Daerah Khusus Ibukota Jakarta, Kota Administrasi Jakarta Selatan, Kecamatan Kebayoran Lama, Kelurahan Pondok Pinang, bersetifikat Hak Milik No. 3747/Pondok Pinang, luas 310 m²$^{2}$, sesuai dengan Gambar Situasi No. 1242/1994, tanggal 24 Februari 1994, berikut bangungan rumah tinggal yang terdaapt di atas tanah itu, setempat di kenal oleh umum Jl. Niaga Hijau 1/10, Jakarta Selatan.

Bahwa kemudian Tergugat V berdalih bahwa dalam melakukan pekerjaan yang dimaksud dimana Membebankan Hak Tanggungan atas tanah objek tanah 
Volume 2 Nomor 2, Desember 2019

E-ISSN: 2655-7347

tersebut karena adanya offering letter (Surat dari bank, dan parallel dengan itu asli sertifikat dan data lainnya diserahkan oleh Kantor Notaris/PPAT Hasan Halim, Jakarta Utara, kepada tergugat V). bahwa sebelum dilangsungkannya penandatangan akta jual beli atas tersebut, Tergugat $\mathrm{V}$ telah melakukan langkah-langkah sebagaimana mestinya, yaitu pengecekan Sertifikat Hak Milik Atas Tanah tersebut di Kantor Pertanahan Jakarta Selatan (selanjutnya disebut Turut Tergugat I), pada tanggal 16 Mei 2016, dengan hasil pengecekan tidak terdapat blokir, tidak terdapat sita jaminan, dan tidak ada catatan hukum lainnya, sehingga tanah dan bangunan bersetifikat tersebut tidak dapat ditransaksikan.

Bahwa kemudian tanggal 18 Juni 2016, balik nama sertifikat hak atas tanah tersebut telah selesai dari atas nama Ir. Sugandi menjadi atas nama Andrie Wijaya, selanjutnya juga telah selesai pengikatannya dengan Hak Tanggungan. Kemudian Asli Sertifikat Hak Milik Atas Tanah dan hak tanggungannya telah Tergugat V serahkan kepada Bank Standard Chartered (selanjutnya disebut Turut Tergugat II) selaku kreditur. Bahwa sehubungan ini adanya perkara Perdata No. 124/Pdt.G/2017 Pn.Jkt.Sel., tersebut, Tergugat V mengakui dalam menjalankan jabatannya termasuk sebagai korban penipuan dan pemalsuan.

\section{B. Pertimbangan Hukum Hakim Dalam Perkara Gugatan Perdata}

Menimbang, bahwa untuk membuktikan dalil bahwa Penggugat adalah pemilik tanah dan bangunan di Jalan Niaga Hijau I No. 10 RT. 002 Rw. 17, Kelurahan Pondok Pinang, Kecamatan Kebayoran Lama, Kota Administrasi Jakarta Selatan, Penggugat telah mengajukan bukti yang relevan dengan dalil tersebut yaitu bukti P-1, P-2 dan bukti saksi Ping Hartono dan Sidhy Irawidya serta dengan adanya pengakuan dari Tergugat II, Tergugat III, Tergugat IV dan Tergugat V, telah terbukti bahwa Penggugat adalah pemilik tanah dan bangunan dengan Sertifikat Hak Milik Nomor 3747/Pondok Pinang yang telah diserahkan 
Volume 2 Nomor 2, Desember 2019

E-ISSN: 2655-7347

kepada Tergugat II oleh anak Penggugat yang bernama Radian Sugandi dan diterima oleh Tergugat III asisten Notaris yang bekerja pada Tergugat II sebagai persyaratan jual beli dengan Tamziz Taryadi (Pembeli) dengan demikian menurut pendapat Majelis, Penggugat telah dapat membuktikan bahwa tanah dan bangunan sengketa dengan Sertifikat Hak Milik No. 3747 adalah milik Penggugat ;

Menimbang, bahwa apakah Para Tergugat dan Turut Tergugat yang mengalihkan Sertifikat Hak Milik Nomor 3747/Pondok Pinang atas nama Ir. Sugandi (Penggugat) menjadi atas nama Andre Widjaya/Andrie Widjaya (Tergugat I) merupakan perbuatan melawan hukum, dipertimbangkan sebagai berikut:

Menimbang, bahwa Perbuatan Melawan Hukum diatur didalam Pasal 1365 KUHPerdata, yaitu tiap-tiap perbuatan melanggar hukum yang menimbulkan kerugian kepada orang lain, mewajibkan orang yang karena salahnya menimbulkan kerugian tersebut mengganti rugi;

Menimbang, bahwa dengan demikian unsur-unsur yang harus dibuktikan adalah ada perbuatan yang melanggar hukum, ada kesalahan, ada kerugian dan ada hubungan kausal antara kerugian dan kesalahan;

Menimbang, bahwa kriteria perbuatan yang melanggar hukum menurut Yurisprudensi ada 4 (empat) yaitu berbuat atau tidak berbuat yang bertentangan dengan kewajiban hukum pelaku, melanggar hak subyektif orang lain, melanggar kaidah kesusilaan, melanggar kepatutan, ketelitian dan kehati-hatian dalam pergaulan hidup masyarakat terhadap orang maupun barang;

Menimbang, bahwa dari bukti-bukti yang diajukan Penggugat maupun Tergugat II, Tergugat III, Tergugat IV, Tergugat V, Turut Tergugat I, dan Turut Tergugat II diperoleh fakta bahwa pada tanggal 27 April 2016 telah diserahkan oleh Radian Sugandi (anak) dari Penggugat kepada Tergugat II melalui Tergugat III berupa asli Sertifikat Hak Milik No 3747/Pondok Pinang atas nama 
Volume 2 Nomor 2, Desember 2019

E-ISSN: 2655-7347

Penggugat, Asli Surat Keterangan No. 0395/1.842.0/14 tanggal 27-2-2014 yang dikeluarkan oleh Lurah Pondok Pinang, Fotocopy KTP dan KK atas nama Penggugat dan DR. Ny. Matulanda. S dan fotocopy PBB tahun 2010 (bukti P-2) sebagai persyaratan penjualan dan pembelian antara Penggugat sebagai penjual dengan Tamziz Taryadi (sebagai pembeli) kemudian tanpa sepengetahuan Penggugat, Tergugat III telah menyerahkan Asli Sertifikat Hak Milik Nomor 3747/Pondok Pinang atas nama Penggugat kepada Tergugat IV, selanjutnya Tergugat IV menyerahkan asli Sertifikat atas nama Penggugat tersebut kepada Tergugat V untuk dibuatkan Akta Jual Beli palsu antara Tergugat I dengan Penggugat, padahal Penggugat sama sekali tidak pernah bertemu dengan Tergugat I dan menanda tangani Akta Jual Beli keatas nama Tergugat I (Bukti $\mathrm{T}-\mathrm{V}-7$ ) dan hal ini juga diakui Tergugat $\mathrm{V}$ dalam jawabannya yang menyatakan dalam pembuatan Akta Jual Beli tersebut termasuk sebagai korban penipuan dan pemalsuan;

Menimbang, bahwa atas dasar Akta Jual Beli yang dibuat secara melawan hukum tersebut, Turut Tergugat I telah menerbitkan Sertifikat Hak atas tanah atas nama Tergugat I dengan nomor Hak Milik 3747/Pondok Pinang, selanjutnya oleh Tergugat I Sertifikat Hak Milik atas nama Tergugat I dijadikan jaminan kredit pemilikan properti kepada Turut Tergugat II dengan dibebani hak tanggungan peringkat pertama Nomor 5204/2016 berdasarkan APHT PPAT Tergugat V tercatat atas nama Turut Tergugat II melalui Kantor cabangnya di Jakarta terdaftar tanggal 29 Agustus 2016 (Bukti T-V-8, 9, 10, 11, 12,13) tanpa melakukan pengecekan terlebih dahulu terhadap tanah dan bangunan mengingat tanah dan bangunan tersebut adalah milik Penggugat dan sampai sekarang secara fisik tanah dan bangunan tetap dikuasai Penggugat dengan demikian Turut Tergugat II kurang teliti dan kurang hati-hati dalam pemberian kredit tersebut; 
Volume 2 Nomor 2, Desember 2019

E-ISSN: 2655-7347

Menimbang, bahwa akibat perbuatan Para Tergugat dan Turut Tergugat sebagaimana tersebut diatas, Penggugat sebagai pemilik yang sah atas tanah dan bangunan yang terletak di Jalan Niaga Hijau I No. 10 Rt. 002/ Rw 017, Kelurahan Pondok Pinang luas 310 M2 telah menderita kerugian dan kerugian tersebut adalah merupakan kesalahan dari Para Tergugat dan Turut Tergugat sehingga tanah dan bangunan milik Penggugat telah disertifikatkan atas nama Tergugat I dan dijadikan agunan di Bank;

Menimbang, bahwa dengan alasan dan pertimbangan hukum sebagaimana tersebut diatas, Majelis Hakim berpendapat bahwa Penggugat telah dapat membuktikan dalil gugatannya, bahwa Para Tergugat dan Turut Tergugat telah melakukan perbuatan melawan hukum.

\section{Data Hasil Penelitian}

Menurut Bapak Risbert bahwa dalam kasus ini tentu ia sudah melanggar kode etik, karena sudah melanggar prinsip kehati-hatian, seharusnya PPAT ini, sepanjang sertifikat asli ada sama yang di pemegang, kemudian nama seritifikat adalah sama dengan sertifikat asli, maka ia berhak menjual atau membuat AJB tersebut. Terkait kasus ini sudah adanya indikasi tindak pidana, walaupun PPAT mengakui di persidangan bahwa ia adalah korban penipuan dan pemalsuan, tapi ia tidak bisa sekedar mengakui bahwa ia korban seolah-olah ia tidak melakukan kesalahan. Karena ia seharusnya tahu pada saat penandatangan AJB, adanya penjual figur atau dengan kata lain bahwa adanya pemalsuan identitas si penjual tanah, kadang-kadang banyak Notaris/PPAT tidak teliti dalam melihat identitas, tanda tangan dan lainnnya.

Dari kasus ini kunci pertama adalah sertifikat, kemudian terkait data kepemilikan antara sertifikat dan data harus sinkron, sehingga dari rangkaian perbuatan hukum yang terjadi dalam kasus ini Notaris/PPAT yang dalam melakukan pembuatan AJB yang mengandung cacat hukum seharusnya 
E-ISSN: 2655-7347

diketahui terlebih dahulu orang yang membawa sertifikat itu, dalam hal ini adalah asisten notaris yang pertama. Bagi seorang PPAT adanya kewajiban dalam melakukan jual beli harus ada pengecekan sertifikat yang diatur dalam PP No. 24 Tahun 1997 tentang Pendaftaran Tanah. Salah satu tugas PPAT sebelum melakukan akta peralihan harus pengecekan terlebih dahulu. Arti pengecekan harus memenuhi beberapa syarat, yaitu:

a. Melampirkan sertifikat asli

b. Data pemilik sertifikat

c. Surat kuasa pemilik sertiifkat

Dari 3(tiga) unsur ini, apabila disanggupi oleh seseorang yang menyerahkan kepada seorang PPAT, maka PPAT tersebut dapat melakukan AJB. Apabila yang datang itu figur atau bukan orang tertera di dalam identitas, maka sudah hal lain bagi PPAT, karena di dalam sertifikat, Kartu Tanda Penduduk, Kartu Keluarga, Surat Nikah pemilik tanah merupakan satu sinergitas bahwa ia adalah pemilik tanah tersebut menurut hukum tanah, siapa pemegang sertifikat asli, yang namanya ada di sertifikat ia dianggap sebagai pemilik sah hak atas tanah, kecuali pihak lain dapat membuktikan selainnya.

Sehingga menurut Bapak Risbert, sepanjang sudah melakukan pengecekan, PPJB selesai, tinggal menunggu pelunasan dari perjanjian awal tersebut seharusnya selesai perjanjian ini.

Mengenai ini, dalam kasus ini apabila ada indikasi pemalsuan, yang telah terbukti dalam persidangan secara jelas dan nyata, maka hakim Pengadilan Negeri menyampaikan putusannya ke Majelis Pembina dan Pengawas PPAT, dari Majelis Pembina dan Pengawas PPAT kemudian menilai dan meneliti terhadap putusan dan pelanggaran dari seorang PPAT yang nantinya Majelis Pembina dan Pengawas PPAT akan mengeluarkan sanksi kepada PPAT tersebut 
Volume 2 Nomor 2, Desember 2019

E-ISSN: 2655-7347

apabila terbukti telah melakukan pelanggaran sebagaimana dimaksud dalam peraturan perundang-undang maupun peraturan lainnya. ${ }^{10}$

Mengenai kasus ini, Bapak Boy Nurdin berpendapat bahwa dalam kasus ini telah terjadi ada pelanggaran kode etik PPAT. Karena dalam serangkaian perbuatan yang dilakukan para tergugat dalam hal ini Notaris/PPAT beserta asistennya telah melakukan perbuatan melawan hukum. Karena adanya upaya seolah-olah mencari keuntungan dengan maksud memakai nama palsu, adanya tipu muslihat ataupun rangkaian kebohongan sehingga adanya kerugian terhadap si pemilik tanah. Sehingga dari serangkaian perbuatan maupun tipu muslihat PPAT tersebut dapat dituntut dengan Pasal 378 KUHPidana dengan ancaman pidana penjara 4 (empat) tahun.

Bahwa selanjutnya dalam kasus ini juga terdapat adanya pemalsuan akta autentik, karena perbuatan PPAT yang tidak hati-hati dalam menjalankan tugasnya. Prinsip kehati-hatian merupakan suatu prinsip yang harus dipegang teguh oleh seorang PPAT dalam menjalankan tugasnya sebagai pejabat umum, oleh karena itu prinsip kehatian-hatian merupakan suatu kewajiban dari PPAT dalam menjalankan tugasnya agar terhindarinya pembuatan akta yang mengandung cacat hukum dikemudian hari, dan seharusnya PPAT harus mengecek terlebih dahulu dokumen-dokumen yang diberikan kepadanya guna pembuatan akta, sebelum melakukan peralihan hak atas tanah ini. Oleh karena itu dalam melakukan perbuatan hukum atau menjalankan tugasnya sebagai seorang PPAT ini, selain dituntut untuk berhati-hati tetapi juga harus tidak berpihak kepada siapapun, sehingga dari perbuatannya dapat dituntut dalam Pasal 266 KUHPidana tentang pemalsuan suatu akta autentik maka dapat diancam pidana penjara paling lama 8 (delapan) tahun.

10 Peneliti, Wawancara, dengan Risbert (Jakarta: Univesitas Tarumanagara, 01 November 2019). 
Volume 2 Nomor 2, Desember 2019

E-ISSN: 2655-7347

Sehingga dari pernyataan di atas, maka dapat ditarik kesimpulan, bahwa dalam pelanggaran kode etik belum tentu adanya tindak pidana, tetapi dalam hal ini adanya tindak pidana maka pasti adanya pelanggaran kode etik. Bahwa dari kasus ini PPAT telah melanggar kewajiban seorang PPAT, yaitu melanggar prinsip kehati-hatian dan kewajiban untuk tidak berpihak kepada siapapun. ${ }^{11}$

Menurut Dr. Gunawan Djajaputra, bahwa Notaris dan PPAT merupakan profesi yang berbeda, walaupun dalam masyarakat awam mengenai Notaris dan PPAT merupakan profesi yang sama. Notaris dan PPAT sebenarnya memiliki fungsi dan tugas yang berbeda, seperti Notaris dalam pembuatan akta bersifat umum dalam hal ini perjanjian dan lainnya, dan PPAT dalam pembuatan aktanya lebih dalam pertanahan. Jika dikaitkan dalam kasus penulis, bahwa menurut beliau harus dilihat terlebih dahulu apakah adanya didasari perjanjian atau tidak. Apabila didasari adanya perjanjian maka dapat digugat secara wanprestasi, sedangkan apabila tidak adanya perjanjian maka digugat secara perbuatan melawan hukum. Untuk membuktikan kesalahan Notaris atau PPAT dalam pembuatan akta yang mengandung cacat hukum harus dibuktikan dalam pengadilan dengan mengajukan gugatan secara perdata, dalam pengadilan tersebut dimana ada tahap pembuktian, sehingga para pihak diberikan kesempatan untuk mengajukan bukti-bukti yang mendukung atau memberatkan pihak-pihak yang terkait, jika pihak Notaris atau PPAT terbukti melakukan wanprestasi atau perbuatan melawan hukum, maka Notaris dan PPAT tersebut dapat dikenakan tanggung jawab secara perdata dengan membayar ganti rugi dan beserta bunga. Apabila Notaris yang melakukan hal tersebut maka dapat dikenai Pasal 44 UUJN No. 2 Tahun 2014 untuk pembayaran ganti rugi, sedangkan PPAT dalam peraturan pemerintah tidak mengatur hal tersebut, sehingga dalam pembuktian pengadilan, apabila memang PPAT tersebut telah

11 Peneliti, Wawancara, dengan Boy Nurdin (Jakarta: Univesitas Tarumanagara, 11 November 2019). 
Volume 2 Nomor 2, Desember 2019

E-ISSN: 2655-7347

melakukan perbuatan melawan hukum dan terbukti secara sah dan patut, maka PPAT harus mengganti kerugian tersebut beserta bunga, dengan melihat unsurunsur sebagai berikut: ${ }^{12}$

1. Perbuatan orang;

2. Kerugian;

3. Kesalahan;

4. Hubungan kausalitas mengenai perbuatan itu halal atau tidak.

\section{Analisis Tanggung Jawab PPAT Dalam Pembuatan Akta Autentik Yang}

\section{Cacat Hukum}

Dalam pembuatan akta autentik, PPAT memiliki tanggungjawab atas segala perbuatan hukum yang telah menjadi kewenangannya berdasarkan aturan hukum yang berlaku seperti halnya dalam pembuatan akta yang dimintakan oleh para penghadapnya. Apabila terbukti dikemudian hari adanya sengketa mengenai akta yang dibuatnya tersebut, baik yang diperselisihkan karena tidak terpenuhinya syarat formil maupun syarat materiil dalam pembuatan akta. Keabsahan sebuah akta memang harus melihat terlebih dahulu kedua syarat tersebut, dimana syarat formil dalam pembuatan akta harus berdasaran pada ketentuan yang telah diatur dalam undang-undang, sedangkan syarat materiil merupakan kepastian tentang materi suatu akta, karena apa yang termaktub dalam akta merupakan pembuktian yang sah terhadap pihak-pihak yang tercantum dalam akta tersebut dan berlaku untuk umum, kecuali ada pembuktian sebaliknya. Jika akta tersebut dalam bentuk surat perjanjian, maka syarat sahnya suatu perjanjian sebagaimana dimaksud dalam Pasal 1320 KUHPerdata harus terpenuhi karena bagian dari syarat materiil. Hal ini merupakan kewajiban bagi seorang PPAT sebagai pejabat umum untuk bertanggung jawab, mandiri serta tidak berpihak kepada siapapun dalam pembuatan yang artinya harus netral. Sehingga kesimpulannya, PPAT dapat

12 Peneliti, Wawancara, dengan Gunawan Djajaputra (Jakarta: Univesitas Tarumanagara, 28 Oktober 2019). 
dimintai pertanggungjawaban atas akta yang dibuatnya jika terjadi adanya pembuatan akta yang tidak memenuhi syarat formil dan materiil sehingga menimbulkan cacat hukum, yang kemudian menimbulkan kerugian pada pihak yang berkepentingan.

Dari kasus yang diteliti penulis, melalui putusan hakim Pengdilan Negeri Jakarta Selatan dalam perkara Nomor 124/PDT.G/2017/PN.JKT.SEL telah menjatuhkan putusan yang menyatakan bahwa PPAT telah bersalah melakukan tindakan melawan hukum karena telah melakukan tindakan hukum pembuatan akta yang mengandung cacat hukum sehingga menimbulkan kerugian pada pihak yang berkepentingan. Dari kasus diatas dimana antara Andre Wijaya (Tergugat I) dan Notaris/PPAT Noor Kholis Adam (Tergugat V) telah membuat akta jual beli tanah tanpa sepengetahuan si pemilik tanah atau Penggugat, akibatnya si pemilik tanah telah dirugikan oleh adanya AJB yang dikeluarkan Tergugat V atau PPAT yang membuatnya, padahal pemilik tanah sudah menjual tanah tersebut kepada Tamziz Taryadi dengan pembuatan PPJB dihadapan Notaris/Tergugat II. Karena dikeluarkannya AJB itu, tanah tersebut dibalik tanah di Kantor BPN dan dibebani hak tanggungan. Dari perbuatan hukum PPAT yang mengeluarkannya AJB tersebut, pihak pemilik tanah telah dirugikan. Oleh karena itu PPAT dapat dikenai tanggung jawab atas pembuatan akta tersebut dengan memperhatikan Peraturan Jabatan PPAT, Kode Etik PPAT, KUHPerdata dan KUHPidana.

1. Sanksi Administratif

PPAT dalam menjalankan tugasnya memiliki sejumlah kewenangan, akan tetapi, di dalam kewenangan tersebut juga memiliki konsekuensi atau sanksi apabila terjadi adanya pelanggaran kewenangan, baik dilakukan secara kekeliruannya maupun kesalahan karena sendirinya dalam masalah administrasi atau juga dapat dikatakan sebagai mal administrasi yang dilakukan oleh seorang PPAT dalam menjalankan tugasnya dalam membuat 
akta autentik mengenai tanah, sehingga tentu dapat menimbulkan konsekuensi atau sanksi hukum.

PPAT harus bertanggung jawab atas pembuatan akta jual beli tanah yang cacat hukum, karena perbuatan tersebut dikategorikan sebagai perbuatan menyalahgunakan kewenangannya, mengingat wewenang seorang PPAT telah disalahgunakan, maka menimbulkan kerugian kepada pihak yang berkepentingan.

Berdasarkan aturan yang tercantum dalam Kode Etik PPAT, PPAT sebagai pejabat umum harus berlandaskan sikap teliti, cermat, dan kehatihatian dalam menjalankan wewenang atau tugasnya, karena PPAT telah mempunyai profesionalitas baik secara teoritis maupun praktisi. Oleh karena itu apabila seorang PPAT telah melakukan kesalahan dalam pembuatan akta, sehingga mengakibatkan akta tersebut menjadi cacat hokum, maka dapat dikatakan telah melakukan penyalahgunaan kewenangan, karena PPAT bersangkutan mengetahui bahwa setiap pejabat umum yang kewenangannya diberikan oleh undang-undang, maka seorang PPAT dituntut untuk melakukan perbuatan hukum sesuai kewenangannya. Keadaan menyalahgunakan wewenang ini semakin jelas apabila adanya unsur kerugian yang diderita oleh pihak yang berkepentingan.

Pertanggungjawaban PPAT terkait kesengajaan maupun kelalaianya dalam membuat akta autentik yang tidak terpenuhinya syarat formil maupun syarat materiil prosedur pembuatan akta PPAT, maka sanksi yang dapat dikenakan PPAT dengan mengacu pada ketentuan Pasal 6 (1) Kode Etik PPAT menyatakan sanksi sebagai berikut:

1. Teguran;

2. Peringatan;

3. Schorsing (pemecatan sementara) dari keanggotaan perkumpulan IPPAT;

4. Onzetting (pemecatan) dari keanggotaan perkumpulan; 
Volume 2 Nomor 2, Desember 2019

E-ISSN: 2655-7347

5. Pemberhentian dengan tidak hormat dari keanggotaan perkumpulan IPPAT.

Berkaitan dengan kasus di dalam penelitian ini, berdasarkan analisis penulis, maka seorang PPAT dalam pembuatan akta autentik yang cacat hukum sehingga menimbulkan kerugian kepada pihak yang berkepentingan dapat dikenakan tanggung jawab. Menurut Pasal 10 ayat (3) PP No. 24 Tahun 2016 menyatakan bahwa seorang PPAT dapat diberhentikan dengan tidak hormat apabila melakukan pelanggaran berat terhadap larangan atau kewajiban sebagai seorang PPAT, Pelanggaran berat ini dapat berupa:

1. Membantu melakukan permufakatan jahat yang mengakibatkan sengketa atau konflik pertanahan;

2. Melakukan pembuatan akta sebagai permufakatan jahat yang mengakibatkan sengketa atau konflik pertanahan;

3. Melanggar sumpah jabatan sebagai PPAT;

4. Membuat akta PPAT tanpa dihadiri oleh para pihak.

Mengenai pemberhentian PPAT karena alasan dalam Pasal 10 ayat (2), (3) PP No. 24 Tahun 2016 tentang PPAT, dilakukan setelah PPAT yang dalam diperiksaan diberi waktu kesempatan mengajukan pembelaan diri kepada Kementerian Agraria dan Tata Ruang. Sedangkan apabila PPAT yang berhenti atau mengundurkan atas permintaan pribadi dapat diangkat lagi menjadi PPAT.

Menurut penulis terkait kasus ini seorang PPAT telah melakukan pelanggaran berat, karenanya telah membuatkan akta autentik yang cacat hukum sehingga menimbulkan sengketa atau konflik pertanahan, dalam hal ini adalah gugatan perdata, dimana seorang pemilik tanah telah dirugikan atas perbuatan PPAT itu, sedangkan itu PPAT selain dikenakan sanksi menurut peraturan perundang-undangan juga akan dikenakan sanksi dalam Kode Etik PPAT berdasarkan Pasal 4 huruf (r) Kode Etik PPAT dimana seorang PPAT yang telah melakukan perbuatan yang melanggar Kode Etik PPAT, antara lain pelanggaran-pelanggaran terhadap: 
Volume 2 Nomor 2, Desember 2019

1. Melanggar aturan jabatan sebagai PPAT atau ketentuan perundangan lain yang terkait.

2. Melanggar ketentuan sumpah jabatan;

3. Melanggar aturan yang dimuat dalam AD/ART organisasi IPPAT tidak boleh dilakukan oleh anggota perkumpulan IPPAT.

Menurut Risbert, terhadap kasus ini selain melanggar peraturan perundang-undangan yang diatas ini, tetapi juga melanggar kewajiban seorang PPAT, yaitu melanggar prinsip kehati-hatian karena tidak mengecek identitas para pihak menghadap kepadanya dalam pembuatan akta autentik itu, sehingga akta tersebut cacat hukum, dan menimbulkan kerugian terhadap pemilik tanah tersebut. ${ }^{13}$

Dari uraian di atas, maka terhadap kasus yang diteliti oleh penulis, jadi PPAT tersebut akan dikenakan sanksi berupa pemberhentian secara tidak hormat karena perbuatannya telah melanggar ketentuan dalam peraturan PPAT dan Kode Etik PPAT berdasarkan PP No. 24 Tahun 2016 Pasal 10 ayat (1) dan (3).

2. Sanksi Perdata

Selain dikenakan sanksi secara administratif, PPAT juga dapat dikenakan sanksi secara keperdataan, hal ini karena adanya kerugian pihak yang bersangkutan, oleh perbuatan hukum seorang PPAT yang tidak sesuai dengan syarat formil dan materiil dalam pembuatan akta.

Dalam kaitannya dalam kasus yang diteliti, bahwa di dalam pertimbangan hakim sudah jelas menyatakan bahwa adanya tindakan melawan hukum yang dilakukan PPAT tersebut. Dalam aturan yurisprudensi ada 4 (empat) kriteria kualifikasi sebagai unsur-unsur yang dapat dikategorikan sebagai tindakan melawan hukum yaitu melaksanakan atau tidak melaksanakan tindakan yang bertentangan dengan kewajiban

\footnotetext{
13 Peneliti, Wawancara, dengan Risbert (Jakarta: Univesitas Tarumanagara, 01 November
} 2019). 
E-ISSN: 2655-7347

hukum pelaku, melanggar hak subyektif orang lain, melanggar kaedahkaedah kesusilaan, melanggar kepatutan, ketelitian dan kehati-hatian dalam pergaulan hidup masyarakat terhadap orang maupun barang.

Dari uraian atas, dikatakan sebagai suatu tindakan melawan hukum tidak diisyaratkan dengan harus adanya keempat kriteria itu, akan tetapi salah satu dari kriteria secara alternatif, sudah cukup terpenuhi pula sebagai tindakan melawan hukum. Oleh karena itu, berkaitan dengan kasus tersebut adanya hak subjektif orang lain yang dilanggar, maka konsekensi hukumnya PPAT tersebut dapat dikatakan telah melakukan tindakan melawan hukum, sehingga PPAT tersebut harus mengganti kerugian terhadap pihak yang dirugikan.

Hal ini juga sependapat menurut Gunawan Djajaputra, apabila seorang PPAT terbukti telah melakukan tindakan melawan hukum yang secara sah telah diputus oleh pengadilan ada konsekuensi hukum yang diterima PPAT karena tindakannya telah merugikan pihak-pihak yang bersangkutan. Dengan melihat adanya unsur adanya perbuatan orang, kerugian, kesalahan dan hubungan kausalitas halal atau tidaknya perbuatan, sehingga apabila telah memenuhi unsur tersebut maka PPAT tersebut dapat dikenakan ganti rugi dan beserta bunga terhadap kerugian yang ditimbulkan oleh PPAT untuk pihak yang merasa dirugikan. ${ }^{14}$

Menurut Pasal 1365 KUHPerdata “Tiap perbuatan yang melanggar hukum, yang membawa kerugian kepada orang lain, mewajibkan orang yang karena salahnya menerbitkan kerugian itu, mengganti kerugian tersebut” berdasarkan ketentuan ini, PPAT dapat dituntut untuk membayar ganti rugi kepada pihak yang dirugikan. ${ }^{15}$ Hal ini dapat dilakukan bila:

\footnotetext{
Peneliti, Wawancara, dengan Gunawan Djajaputra (Jakarta: Univesitas Tarumanagara, 28 Oktober 2019).

15 Mustofa, Tuntutan Pembuatan Akta PPAT, (Yogyakarta: KaryaMedia, 2010), 8.
} 
Volume 2 Nomor 2, Desember 2019

E-ISSN: 2655-7347

a. Akta PPAT hanya mempunyai kekuatan pembuktian dibawah tangan;

b. Akta PPAT batal demi hukum.

Terkait bila PPAT dapat dijatuhi penggantian biaya, ganti rugi dan bunga, harus dibuktikan terlebih dahulu apabila:

a. Adanya kerugian yang diderita;

b. Antara kerugian yang diderita dan pelanggaran atau kelalaian dari PPAT;

c. Pelanggaran atau kelalaian tersebut disebabkan kesalahan yang dapat dipertanggungjawaban kepada PPAT yang bersangkutan.

Karena para PPAT secara bersamaan dan telah terbukti telah membuat akta autentik yang tidak diketahui oleh si pemilik asli sertifikat hak milik atas tanah yaitu Ir. Sugandi, maka PPAT tersebut dapat dimintai pertanggungjawaban dengan meminta ganti rugi atas kerugian yang dideritanya.

3. Sanksi Pidana

Penjatuhan sanksi dapat dilakukan terhadap seorang PPAT sepanjang PPAT tersebut telah melakukan kejahatan atau tindak pidana lainnya seperti pemalsuan akta autentik. Syarat formil dan materiil merupakan aspek yang harus dipenuhi dalam pembuatan akta autentik mengenai akta jual beli tanah sebagai tugas PPAT.

Terkait ini, menurut Dr. Boy Nurdin, S.H., M.H., berhubung di dalam kasus tersebut Notaris/PPAT Noor Kholis Adam (Tergugat V) telah mengakui bahwa ia adalah korban penipuan dan pemalsuan, oleh karena itu, seorang PPAT dapat dikenakan Pasal 264 Jo. 378 KUHPidana karena telah melakukan pemalsuan terhadap akta autentik dan juga telah menimbulkan potensi kerugian kepada si pemilik tanah. ${ }^{16}$ 2019).

Peneliti, Wawancara, dengan Boy Nurdin (Jakarta: Univesitas Tarumanagara, 11 November 
Volume 2 Nomor 2, Desember 2019

E-ISSN: 2655-7347

Jadi, terkait kasus ini PPAT dapat dikenakan sanksi Pidana sebagaimana dimaksud dalam Pasal 264 KUHPidana diancam pidana penjara paling lama 8 (delapan) tahun, dan 378 KUHPidana diancam pidana penjara paling lama 4 (empat) tahun.

\section{Penutup}

\section{A. Kesimpulan}

Tanggung jawab atau sanksi yang akan dikenakan oleh seorang PPAT terhadap pembuatan akta yang cacat hukum atau terbukti melakukan pelanggaran dalam menjalankan tugas, fungsi serta jabatannya sehingga akta yang dibuatnya telah merugikan pihak-pihak yang berkepentingan dengan di dasari pembuatan akta yang menyimpang dari syarat formil dan materiil dalam pembuatan suatu akta, maka PPAT tersebut akan dikenakan sanksi sebagai berikut:

1. Sanksi Administratif: PPAT yang melakukan pembuatan akta yang cacat hukum akan dikenakan sanksi berupa pemberhentian secara tidak hormat karena telah melanggar peraturan perundang-undangan, prinsip kehatian-hatian dan Kode Etik;

2. Sanksi Keperdataan: Apabila akta yang dibuat oleh seorang PPAT, kemudian akta tersebut adalah perbuatan melawan hukum, maka PPAT dapat dimintai tanggung jawab berupa penggantian biaya dan ganti rugi beserta bunga.

3. Sanksi Pidana: Apabila seorang PPAT telah secara hukum, telah memenuhi unsur-unsur suatu kejahatan pidana, dalam hal ini pemalsuan suatu akta autentik. Maka PPAT akan dikenakan Pasal 266 KUHPidana dengan sanksi pidana diancam penjara paling lama 8 (delapan) tahun, dan Pasal 378 KUHPidana dengan sanksi pidana diancam penjara paling lama 4 (empat) tahun. 
Volume 2 Nomor 2, Desember 2019

E-ISSN: 2655-7347

\section{B. Saran}

Berdasarkan kesimpulan di atas, maka terdapat saran-saran yang diberikan sebagai bentuk pencegahan agar tidak terulangi perbuatan tersebut:

1. PPAT dalam menjalankan tugasnya seharusnya bertindak dengan penuh tanggungjawab, mandiri, jujur, teliti dan hati-hati serta tidak berpihak kepada pihak siapapun dengan berlandaskan nilai-nilai yang hidup baik di masyarakat dan mengacu pada kaidah moral yang berlaku. PPAT dalam menjalankan tugasnya sebagai pejabat umum haruslah berlandaskan pada peraturan perundang-undangan yang berlaku, sehingga PPAT tersebut tidak dituntut dari segi administrasi, perdata dan pidana.

2. Seharusnya Majelis Pembina dan Pengawasan profesi Pejabat Pembuat Akta Tanah selalu mengawasi PPAT secara rutin dalam bentuk menerima laporan masyarakat, membuat tim investigasi, membuat laporan tahunan pengawasan serta menindak PPAT yang telah melakukan pelanggaran-pelanggaran sebagaimana dimaksud dalam peraturan perundang-undangan dan melakukan sosialisasi terhadap PPAT dalam menjalankan tugasnya, sehingga akan meminimalisir adanya pelanggaran-pelanggaran yang dilakukan oleh PPAT dikemudian hari.

3. Memberikan pengarahan atau seminar melalui organisasi PPAT, BPN dan pihak akademisi dalam bidang perdata yang memfokuskan dalam pertanahan, hal ini agar PPAT mengetahui informasi terkini mengenai pertanahan.

\section{DAFTAR PUSTAKA}

\section{A. Buku}




\section{Jurnal Huknm Adigamă}

SANKSI YANG DITERIMA OLEH PEJABAT PEMBUAT

AKTE TANAH DALAM PEMBUATAN AKTA AUTENTIK YANG CACAT HUKUM

(STUDI PUTUSAN: PN JAKSEL

Volume 2 Nomor 2, Desember 2019

E-ISSN: 2655-7347

Az, Santoso, Lukman. dan Yahyanto. Pengantar Ilmu Hukum. (Malang: Setara Press, 2016.)

Fuady, Munir. Perbuatan Melawan Hukum Pendekatan Kontemporer. (Bandung: PT Citra Aditya Bakti, 2013.)

Hs, Salim H. Teknik Pembuatan Akta Pejabat Pembuat Akta Tanah (PPAT). (Jakarta: Rajawali Pers, 2016.)

Marzuki, Mahmud, Peter. Penelitian Hukum. (Jakarta: Kencana Prenada Media Group, 2006.)

Muladi, dan Barda Nawawi Arief, Perbandingan Hukum Pidana. (Jakarta: Raja Grafindo Persada, 2002.)

Mustofa. Tuntutan Pembuatan Akta-Akta PPAT. (Yogyakarta: KaryaMedia, 2010.)

Notohamidjojo, O. Soal-Soal pokok Filsafat Hukum. (Salatiga: Griya Press, 2011.)

\section{B. Website}

Aries, Albert. "Perjanjian Pengikatan Jual Beli sebagai Alat Bukti”, https://m.hukumonline.com/klinik/detail/ulasan/lt53d8fec20b060/perjanjianpengikatan-jual-beli-sebagai-alat-bukti, Diakses tanggal 26 September 2019. 